\title{
Good Invaders? The Occupation Policy of the Spanish Blue Division in Northwestern Russia, |94|-| 944
}

War in History 20I8, Vol. 25(3) 36I-386

(C) The Author(s) 2017

Reprints and permissions: sagepub.co.uk/journalsPermissions.nav DOI: I0.II77/09683445I6666422 journals.sagepub.com/home/wih

\section{Xosé M. Núñez Seixas}

Ludwig-Maximilians-Universität, Munich

\begin{abstract}
Between 194I and 1944, the Spanish Division of Volunteers took part in the Russian campaign as a unit integrated in the German Wehrmacht. Post- 1945 war memoirs and even some historians have suggested that the 'Blue' Division was exceptional for their benign treatment of civilians and prisoners, distanced from the German War of Extermination. This image has not been subjected to critical enquiry. To what degree were the Spanish troops different from other Wehrmacht troops? Was the collective behaviour of the Spanish soldiers determined by the circumstances they encountered at the front, or was it related to their prior political socialization?
\end{abstract}

\section{Keywords}

Eastern Front, Second World War, war volunteering, Blue Division, occupation

The Spanish Division of Volunteers (División Española de Voluntarios) was set up by the Franco Regime in early summer, 1941, to take part in the Russian campaign as a unit the 250th Spanish Volunteers Division - integrated within the German Wehrmacht. From 24 June through to the first week of July 1941, hundreds of volunteers joined what would become known as the División Azul, the 'Blue Division' (BD), which was initially composed of around 17,000 combatants. They were recruited by both the Spanish Fascist Party, the Falange, which provided most of the rank-and-file soldiers, and the Spanish

\footnotetext{
Corresponding author:

Xosé M. Núñez Seixas, Ludwig-Maximilians-Universität, Historisches Seminar, Lehrstuhl für die Europäische Geschichte des 19. und 20. Jahrhunderts, Geschwister-Scholl-Platz I, D-80539 München, Germany. Email: X.Nunez@Imu.de
} 
Army, which supplied the officer and non-commissioned officer corps. The majority of the volunteers recruited in the summer of 1941 and throughout 1942 were strongly motivated by anti-communism; and up to 20-25 per cent of them also shared Fascist tenets. High casualties on the harsh Eastern Front created the need for replacements and nearly 30,000 more volunteers were sent from Spain to Russia throughout late autumn of 1943 . Almost 5,000 soldiers died. The Spaniards were deployed in the northern area of the Eastern Front, under the command of the Army Group North, first on the Volkhov Front (October 1941-August 1942), and later at the southern corner of the siege of Leningrad (until March 1944). ${ }^{1}$

Post-1945 memoirs of war veterans and even some professional historiography suggest that the Blue Division was exceptional among the forces occupying the Eastern Front for their extraordinarily benign treatment of the Russian civilian population, Jews, and Red Army prisoners. The presence of the Spanish volunteers in Russia was presented as an anti-communist venture, devoid of national-socialist sympathies and distanced from the Third Reich's War of Extermination. ${ }^{2}$ However, this image of the Iberians as 'good invaders' has rarely been subjected to critical enquiry or historical questions similar to those addressed in the vast historiography concerning the conduct of German troops and their allies on the Eastern Front. To what degree were the Spanish troops different from other Wehrmacht troops? Was the Blue Division truly the peaceful oasis it was made out to be within the Ostheer, with respect to their treatment of the civilian population and prisoners of war? In the war of extermination were the Spaniards an exception or just a variation? Was the collective behaviour of the Spanish soldiers determined by the brutalizing circumstances they encountered at the front, or was it related more to prior political socialization and ideological indoctrination of the volunteers, which conditioned their attitudes towards the act of killing? ${ }^{3}$ The answers will come

1 On the military history of the Blue Division, see a complete description in Xavier Moreno Juliá, La División Azul. Sangre española en Rusia, 1941-1945 (Barcelona, 2004); José L. Rodríguez Jiménez, De héroes e indeseables. La División Azul (Madrid, 2007); Wayne Bowen, Spaniards and Nazi Germany: Collaboration in the New Order (Columbia, 2000); and Xosé M. Núñez Seixas, Die spanische Blaue Division an der Ostfront (1941-1945): Zwischen Kriegserfahrung und Erinnerung (Münster, 2016); also, from Russian historiography, see Boris Kovalev, Dobrovol'ci na cyzoj voyne. Ocerki istorii golyboj divizii (Veliki Novgorod, 2014), and Aleksei V. Elpatevskij, Golubaja divizija: voennoplennye i internirovannye ispancy $v$ SSSR (Saint Petersburg, 2015).

2 For more details, see Xosé M. Núñez Seixas, “Russland war nicht schuldig”. Die Ostfronterfahrung der spanischen Blauen Division in Selbstzeugnissen und Autobiographien, 1943-2004', in Stig Förster, Karen Hagemann, and Michael Epkenhans (eds), Soldat und Gesellschaft. Biographien und Selbstzeugnisse in der Militärgeschichte (Paderborn, 2006), pp. 236-67.

3 For the 'situationist' argument, which stresses the effects of the combat environment on the brutalization of German soldiers' conduct, see Sönke Neitzel and Harald Welzer, Soldaten. Protokolle von Kämpfen, Töten und Sterben (Frankfurt a.M., 2011). For the argument concerning Nazi indoctrination of German soldiers and officers as a necessary prerequisite for their brutalization, see Omer Bartov, The Eastern Front, 1941-45, German Troops and the Barbarisation of Warfare (Houndmills/New York, 2001 [1985]). A recent reappraisal of this thesis is in Felix Römer, Kameraden. Die Wehrmacht von innen (Munich/Zürich, 2012). 
through a sociocultural focus on the experiences of the Iberian volunteers, that explores their perception of the enemy, of Russia, and of the Jews while also empirically analysing their behaviour towards civilians, prisoners, and Jews. ${ }^{4}$ This approach looks at the context in which they acted, through a combined and selective use of different sources.

Nazi Germany embarked on a War of Extermination aimed at many segments of the Soviet population. Key practices involved denying Soviet soldiers civilized treatment, eliminating political commissars, working to annihilate the Jewish population, widening the margins for applying military justice to the civilian population, and ignoring their need for provisions. Many of these premises were outlined in the Directives for Troop Conduct in Russia (19 May 1941), the 'Commissar Order' (6 June 1941), the 'Decree regarding the exercise of war jurisdiction' (13 May 1941), and instructions regarding the treatment of prisoners of war (16 June 1941). ${ }^{5}$ Some of these guidelines were soon adapted to the Spanish troops as Directivas para la conducta de la tropa en Rusia, which identified Bolshevism as 'the moral enemy of the new Europe'. The battle was aimed against their 'corrosive ideas and representatives', for which 'the fight requires robust, impartial action against all Bolshevik elements, such as agitators, snipers, saboteurs or Jews; and complete elimination of all resistance, whether active or passive'. In the same vein, towards 'all members of the Red Army, including the prisoners' a 'most severe attitude and utmost care should be observed, as they will most likely employ treacherous methods in combat'. They branded the 'Asian soldiers of the Red Army', who were 'impervious, inscrutable, insidious and insensitive', as particularly dangerous. When entire units were captured, 'the commanders should be immediately separated from the rest of the troops'. A significant portion of the civilian population was reportedly anticommunist, but 'the utmost caution should be employed when speaking to the population and when addressing women'. Looting was forbidden, but 'merchandise of all types ... especially victuals and fodder, fuel and clothing, should be preserved and impounded' 6 These orders were somewhat softened by the Instrucción General 3.005 issued by the Blue Division General Staff in August 1941, which stipulated that the inhabitants of occupied territories and their possessions were to be respected, requisitions were only to be carried out as compensation, prisoners were to be treated well, and injured enemies were to receive care. Spies and snipers should not be executed on sight, but delivered alive to higher authorities for internment in prisoner camps. ${ }^{7}$

4 On the behaviour of the Spanish volunteers towards the Jews they encountered in Eastern Poland and the Baltic countries, see Xosé M. Núñez Seixas, ‘¿Testigos o encubridores? La División Azul y el Holocausto de los judíos europeos: Entre Historia y Memoria’, Historia y Política 26 (2011), pp. 259-90.

5 The literature on the German-Soviet war is vast. Some recent attempts at synthesis can be found in Christoph Hartmann, Wehrmacht im Ostkrieg: Front und militärisches Hinterland 1941/42 (Munich, 2009); Stephen Fritz, Ostkrieg. Hitler's War of Extermination in the East (Lexington, 2011); Christoph Hartmann et al., Der deutsche Krieg im Osten 1941-1944. Facetten einer Grenzüberschreitung (Munich, 2009).

6 Directivas para la conducta de la tropa en Rusia, G.S. 2nd section, n.d., Archivo General Militar Ávila (AGMAV), 2003/5/1/4.

7 Spanish Volunteers Division (DEV) General Staff, Amplación de Normas Jurídicas internas $y$ de Derecho Internacional, AGMAV 2005/4/2/1. 
There were petitions from several German Division commanders asking for it to be repealed, as it only seemed to encourage enemy resistance. However, shortly before the Iberians arrived at the front, Hitler ratified the Order. ${ }^{8}$ The war was certainly more static and less vicious in the area covered by the Army Group North: of the minimum estimate of 2,253 documented executions of commissars in the first year of war, only 17.32 per cent (405) were carried out by this Group. Between October and December 1941, the total number was 101 , which came to 15.2 per cent. This figure rapidly declined in the first months of 1942. ${ }^{9}$ However, there is no empirical evidence so far that the Commissar Order was ever communicated to the Spanish officers. It is likely that orders were followed and political commissars were summarily taken aside and shot. It is also possible that Spanish officers would spare their troops from such an act - as occurred in certain German units - by ordering the transfer of the commissars to BD high command, where they would be handed over to the Germans. However, some data suggests that the Spanish command and officers were aware of these instructions, particularly when the German Army Corps - which the BD answered to - sent orders to repeal them in specific operations. For instance, to encourage the surrender of the Soviet units surrounded in the Volkhov pocket (March-June 1942), Instruction 2018 from 12 May 1942 ordered the use of propaganda promising good treatment to whoever surrendered arms. 'The troops shall promptly be made aware of the fact that it is forbidden to shoot political commissars, or those who voluntarily join our ranks. These commissars shall be subjected to the same treatment as the rest of the prisoners. ${ }^{10}$ Clearly, it would be senseless to forbid the execution of commissars unless this was the usual practice. Similarly, in May 1943 the Spanish General Staff received notification from Army Corps L, stating that political commissar prisoners were ordered to 'voluntarily offer themselves for employment in German legions', as 'it was evident to the Russian Command that we recently stopped shooting Russian commissars when they are captured'. ${ }^{11}$

\section{Spanish Forces in Occupied Territory: An Idyllic Relationship?}

To what extent can we empirically corroborate the benign image of the Spanish occupation policies on the Eastern Front? To begin, the German perception of this Iberian peculiarity was rather minimal. The close relations between Spanish troops and Russian civilians were not scandalizing enough to merit mention in any Wehrmacht report, nor did the Germans always behave so differently from the Spaniards. ${ }^{12}$ However, the

8 Oberkommando des Heeres (OKH) Order, 2 October 1941 Bundesarchiv-Militärarchiv Freiburg im Breisgau (BA-MA), RH 19II/123.

9 Felix Römer, Der Kommissarbefehl. Wehrmacht und NS-Verbrechen an der Ostfront 1941/42 (Paderborn, 2008), pp. 581-96.

10 2nd section of BD GS, Instrucción num. 2018, 12 May 1942, AGMAV 2005/18/1/6.

11 Comuniqué of the Head of General Staff of Army Corps L, 3 May 1943 (translated), AGMAV 2007/5/3/1.

12 See Jürgen Kilian, Wehrmacht und Besatzungsherrschaft im Russischen Nordwestern 19411944. Praxis und Alltag im Militärverwaltungsgebiet der Heeresgruppe Nord (Paderborn, 2012), pp. 189-240. 
relationship between a civilian population and an occupying army is always complex, even when the locals do not sympathize with the regime the invading force seeks to topple. The need to survive in an environment of scarcity and uncertainty motivated many civilians to find common ground and avoid open confrontation with the invaders. This created a dichotomy that distinguished the impersonal occupying force from the individual occupiers, with whom amicable relations were often formed. Eventually, social conventions began to crumble; flirting or sympathizing with the occupiers carried the inherent risk of developing a sense of closeness. ${ }^{13}$

Moreover, a delicate balance existed between the Russian peasants and the German army in the Army Group North area. With a more static war and less partisan activity than in the Army Groups Centre and South, the peasants provided the invading soldiers with food and housing. Post-war memoirs and accounts suggest that Germans were less hated by the peasants on the Volkhov and Leningrad fronts than Russian collaborationists, Latvians, and the Estonian auxiliary troops. Willingly or otherwise, the village mayors (stárosta, elders) and peasant families often cooperated with the occupiers, and reported the guerrilla groups who seized the peasant's possessions without a second thought. ${ }^{14}$

\section{Exotic and Undisciplined Occupiers}

The Spanish soldiers were already implicated in a series of minor incidents involving the peasantry during their first march on foot from Eastern Poland to the Russian Front (August-September 1941). In response to first complaints from the German liaison officers, Spanish commander-in-chief General Agustín Muñoz-Grandes issued an edict reminding the soldiers that 'any attack to people, property, or unauthorized requisitions could be considered an infraction of the rights of the people against devastation or looting' and punishable under Article 233 of the Spanish Military Code. ${ }^{15}$ However, the behaviour of the BD did not alter upon entering Russian territory; in late September, a German unit informed their superiors that a passing 'division of Spanish soldiers' had requisitioned livestock and chickens from local peasants in the village of Isifowo. ${ }^{16}$ Spanish troops arrived at the rearguard station in Nowo-Sokolniki - the halfway point in their transfer to Volkhov - between 29 September and 13 October. The local German military police was ineffective in keeping the Spanish soldiers from engaging in looting

13 See the anonymous diary of a Berlinese woman describing the arrival of Soviet troops and the complex relations with the occupying forces: Eine Frau in Berlin. Tagebuchaufzeichnungen vom 20. April bis 22. Juni 1945 (Frankfurt a.M., 2003). Some observations concerning Soviet women during the occupation in I. Rebrova, 'Überlebensstrategien von Frauen in den besetzten Gebieten und in Partisaneneinheiten. Kriegsalltag und genderspezifische Erinnerung', in Babette Quinkert and Jörg Morré (eds), Deutsche Besatzung in der Sowjetunion 1941-1944. Vernichtungskrieg, Reaktionen, Erinnerung, (Paderborn, 2014), pp. 276-95.

14 See for example the report of Sicherungsregiment 107, 8 March 1942 (BA-MA, RH 20-16/99).

15 Edict by Agustín Muñoz-Grandes, 3 September 1941 (AGMAV 1978/13/5/1).

16 Report by Sonderführer Walter, Bautrupp II, 29 September 1941 (BA-MA, RH 19III/774). 
and intimidation. They destroyed the station searching for firewood, raided the town, looted warehouses, and requisitioned livestock and grains from peasant households. The Spanish officers apologised for the soldiers' behaviour, saying that their actions corresponded to their hatred for communism. ${ }^{17}$

The arrival of the Spaniards to the Volkhov Front certainly began chaotically; they lodged with the local residents in nearby villages, disrupting the routines the peasant families had become more or less accustomed to under German rule. The BD General Staff ordered that behaviour towards the locals be 'prudent and proper', avoiding 'injustice, coercion and violence, ... as well as familiarity, which could be subject to espionage'. ${ }^{18}$ However, Germans soon began receiving complaints from peasants regarding the Iberians' plundering of food, livestock, and warm clothing. ${ }^{19}$ They also looted 'exotic souvenirs', especially Orthodox icons. It is difficult to discern how much of what the soldiers took corresponded to larceny, church requisitions, and other forms of acquisition or bartering, all of which formed a part of the Division's daily life.$^{20}$ In November 1942 , a Spanish volunteer described his personal booty: 'I found a little Russian suitcase, in which I plan to take four books and icons if possible, and I do believe it to be so. It's not much, and certainly not "pretty" - there was quite the icon hunt around these houses for the first few days - but enough to be a souvenir.'21

The Germans attributed such behaviour to relaxed discipline, mismanagement by illtrained Spanish non-commissioned officers (NCOs) who had entered the ranks of the Army during the Spanish Civil War, the indifference of the BD High Command, and, especially, the hierarchical stance of the Division's quartermaster, who distributed much to the officers and little to the soldiers. ${ }^{22}$ This lack of efficiency in the provisioning system had been a feature of the Spanish army since the colonial wars of 1895-8 and 190725, and was apparent during the foot march to Russia. By November 1941, the Army Group North was seriously considering replacing the BD quartermaster with an annexed department under German command. ${ }^{23}$ This may have led the discontented Spanish

17 See the order of the local Nowo Sokolniki command, 5 October 1941; reports of station officer Seifert, 13 October 1941, and the Vilnius Transport Command, 16 October 1941; reports of Local Command I (V) 293 Nowo Sokolniki and V 181, 21 and 22 October 1941; and Military Police report, Nowo Sokolniki, 20 October 1941 (BA-MA, RH 19III/774).

18 DEV, 2nd section GS, General Instruction 2009, 19 October 1941 (AGMAV 3736/5).

19 However, these reports tended to blame foreign allies or neighbouring divisions for unorthodox behaviour, which could have been the doing of Germans. See Kilian, Wehrmacht, pp. 218-19.

20 Serguei Glezerov, Ot nenavisti $k$ primireniiu. Neizvestnaia voina pod Leningradom (St Petersburg, 2006), p. 137; War Diary of Enrique Sánchez Fraile, cited by Jorge Martínez Reverte, La División Azul (Barcelona, 2011), p. 375.

21 Gregori to Luis Romero, 8 November 1942 (University of California San Diego LibraryManuscripts Section 563).

22 Dionisio Ridruejo to Marichu de la Mora, 24 October 1941 (Archive of Ridruejo Family, Barcelona).

23 See reports by liaison officer Dr Gutzschebauch, 2-10 October 1941, as well as reports to the IA department of the Army Group North, 2 November 1941, OKH to Army Group North, 3 November 1941, and of General von Chappuis to the Supreme Command of the 16th Army, Grigorowo, 17 November 1941 (BA-MA, RH 19 III/774). 
soldiers to provision themselves from the civilian population, as their German comrades had been doing for weeks and months. Violence was not always necessary. Upon arriving at the front, Sergeant Ramón Abadía described how easy it was to obtain food from the villagers, whom he regarded - like many of his comrades in arms - as good savages: 'with a little chocolate and some sweets we can trick them into giving us milk and potatoes ... probably using the same methods as Columbus did when he discovered the Americas and the Indians'. ${ }^{24}$

There was not much to requisition. The local food situation in the rearguard of the Volkhov Front was critical since October 1941. Subjected to Wehrmacht demands, the peasants had already sold their livestock and almost everything of value they owned, including coats and boots. It was a poor county to begin with, with very little mechanized agriculture, and only half of the fertile lands could be farmed in that area. In October 1941, many women, children, and elderly began to withdraw to the rearguard from areas close to the front. On 24 October, the Army Group North command drily noted that 'it seems that sooner or later these people will all die of starvation' ${ }^{25}$

The unruly conduct of the BD towards the peasants had already alarmed the German liaison staff by late October 1941. They had caught wind of the pervasive lack of discipline in the relations between the Spanish volunteers and the civilian population, as well as the indiscriminate and sometimes coercive plundering of food and livestock. The Russian peasants themselves even complained to the Spanish command. ${ }^{26}$ The situation peaked with the Spanish soldiers' 'lack of control with women', which generated 'distasteful scenes' and the threat of propagating venereal diseases. ${ }^{27}$ Adding to the continual requisitions, the 'rapes and other nuisances to the civilian population' made the exasperated locals less cooperative in the anti-partisan fight. ${ }^{28}$ The BD General Staff recorded few cases against soldiers for 'dishonest abuse'. ${ }^{29}$ However, in December 1941 complaints even reached General Franco and the Spanish Minister of War. Confidential reports described the 'unsavoury characters in the Division, who rob, murder and burn whatever they wish', as well as the fact that officers 'had to watch the troops, to avoid

24 Kilian, Wehrmacht, 215-17; Luis A. Palacio Pilacés, Tal vez el día. Aragoneses en la URSS (1937-1977), el exilio y la División Azul (n.p., 2013 ), vol. I, p. 548.

25 Report of Group IV W of 16th Army, 29 October to 21 December 1941 (BA-MA, RH 20-16/1100); Jörn Hasenclever, Wehrmacht und Besatzungspolitik in der Sowjetunion. Die Befehlshaber der rückwärtigen Gebiete 1941-1943 (Paderborn, 2010), pp. 305-9; Army Group North War Diary, entry dated 24 October 1941 (BA-MA, RH 19III/168).

26 See minutes of the GS 2nd section, 28 December 1941, AGMAV 2005/8/3/1.

27 Captain Collatz to Army Group North, 23 October 1941 (BA-MA, RH 19III/774).

28 Captain Collatz to Army Group North, 5 November 1941 (BA-MA, RH 19III/774). See testimonies of sexual assault on Russian women by Germans and Spaniards in the memoirs of private Francisco Manero (Palacio Pilacés, Tal vez el día, vol. I, pp. 551-2), as well as in the unpublished memoirs of soldier Benigno Cabo (1944), Diario de guerra de Benigno Cabo García (Archive of Jorge Villena Cabo, Madrid), p. 132. Russian eyewitness accounts can be found in Kovalev, Dobrovol'cí, p. 347.

29 Only one occurred between November 1941 and August 1942 (GS Order 103, 16 July 1942, AGMAV 3736/6). 
them requisitioning everything they found in the neighbouring villages; as these were frequent, embarrassing cases' ${ }^{30}$ The lack of appropriate equipment for surviving the winter aggravated the situation. When necessary, the Spaniards - and others - took felt boots, hats, and coats from the peasants, leaving them defenceless against the winter cold. ${ }^{31}$ The delay of the Christmas bonus dispatched from Spain, and its scarcity compared to what was promised, generated additional discontent among the troops in late December $1941 . .^{32}$

Aside from their prejudice against the Spanish - which had surfaced among the officers of the Condor Legion during the Spanish Civil War ${ }^{33}$ - the German command concluded that the structural cause of BD conduct stemmed from the hierarchic culture of the Spanish military. The chief commander of the Army Corps XXXVIII attributed the 'brutal conduct of the Spanish soldiers' to the lack of discipline in the BD, pointing out how 'the best food is unabashedly eaten by the officers as extra rations'. In December 1941, the commander of the 16th Army demanded from Berlin that the divisionarios be relieved of their duties, to keep their lack of discipline from spreading to the German soldiers. ${ }^{34}$ Not only were the troublesome soldiers jeopardizing the Wehrmacht's honour, their anarchic actions could lead the civilian population to overcome their fear of reprisal and support the partisans. Of course, German soldiers also occasionally created disturbances, but these were subject to Wehrmacht discipline. Systematic exploitation and more or less rational plundering was entirely different from uncontrolled requisitions that did not benefit the occupying army collectively. ${ }^{35}$

The BD enjoyed the privilege of not being subject to Wehrmacht military justice. This troubled the Germans, as they could not always impose their discipline on their allies. In November 1941, when two Spanish soldiers killed the town elders of Grigorowo and

30 Secret report by a surgeons' commission that visited Germany and Poland, December 1941, reproduced in Documentos inéditos para la historia del Generalísimo Franco (Madrid, 1992), vol. II-2, pp. 404-19; report to General Varela, 22 December 1941, in Archivo Histórico Municipal de Cádiz-Fondo General Varela (AHMC-FGV), C. 115.

31 Testimonies of Aleksandr P. Jaschin, Schutschkova V. Aleksandrovna, and Garachova Ivanovna, among others, in Kovalev, Dobrovol'ci na, pp. 354-9.

32 Pamphlet ¿Qué ha pasado con el Aguinaldo? N.d. [ca. February/March 1942], AGMAV 2005/16/2/13.

33 Stefanie Schüler-Springorum, Krieg und Fliegen. Die Legion Condor im spanischen Bürgerkrieg (Paderborn, 2010), pp. 75-81.

34 Reports of General von Chappuis, 8 December 1941, and General Busch to Army Group North, 4 December 1941 (BA-MA, RH 20-16/67).

35 Omer Bartov, Hitler's Army, Soldiers, Nazis, and War in the Third Reich (Oxford and New York, 1991), pp. 76-78; Kilian, Wehrmacht, pp. 220-5. As with the Hungarian case, German reports tended to exaggerate their concern for the civilian population whenever others were responsible for misconduct. See Truman O. Anderson, 'A Hungarian Vernichtungskrieg? Hungarian Troops and the Soviet Partisan War in Ukraine, 1942', Militärgeschichtliche Mitteilungen 58 (1999), pp. 345-66, and Krisztian Ungváry, 'Das Beispiel der ungarischen Armee. Ideologischer Vernichtungskrieg oder militärisches Kalkül?' in Christoph Hartmann, Johannes Hürter, and Ulrike Jureit (eds), Verbrechen der Wehrmacht. Bilanz einer Debatte (Munich, 2005), pp. 98-106. 
Novgorod, the culprits were only sanctioned by BD command after significant pressure from the Germans. ${ }^{36}$ In December 1941, the Army Corps XXXVIII began to fear that incessant BD pillaging would make the peasants unwilling to collaborate in reporting sightings of Soviet incursions. ${ }^{37}$ Three months later, the Army Corps Martial Court explicitly indicated that the Blue Division was responsible for all major discipline issues within their jurisdiction and that no significant measures had been taken to address the problem. At that point, the Germans decided to arrest Spaniards caught pillaging or stealing, and to incarcerate them for several days before handing them over to the Spanish military justice. The conduct of the divisionarios even led to relaxed discipline in the German 126th Infantry Division. ${ }^{38}$ However, other German divisions that had little or no contact with their Spanish comrades were also involved in aggression and mistreatment of the civilian population. ${ }^{39}$ Spaniards were not necessarily an exception.

The relief battalions arriving from Spain from March 1942 onwards, in which the proportion of wholehearted Fascists was even less, were no better behaved than their predecessors. Food theft was common during train stops in Polish, Baltic, or Russian territory. In December 1942, General Emilio Esteban-Infantes took command of the BD, which had been reassigned to the southern front of the Leningrad blockade. The troops began to receive better provisions of food and winter clothing, thanks to an increase in supplies from Spain. ${ }^{40}$ A better quartermaster and German insistence also helped to improve daily relations between the divisionarios and the civilian population.

\section{Coexisting with the Enemy}

Generally speaking, the Volkhov and Leningrad fronts were panoramas of hunger and desolation. Some records show that the Spaniards were aware of the terrible living conditions in the besieged city, thanks to the stories of Soviet prisoners. ${ }^{41}$ Misery was the status quo in the rearguard of the occupied area as well. In the village of Vyritsa, for example,

36 Manuel Iglesias-Sarria, Mi suerte dijo sí. Evocación autobiográfica de Guerra y Paz (1918-1945) (Madrid, 1987), p. 282. The German version in War Diary of the XXXVIII. Army Corps, entry dated 18 November 1941 (BA-MA, RH 24-38/51). The main detainee was condemned and repatriated in January of 1942 (Report from the Dirección General de Seguridad, Madrid, 27 January 1942, AHMC-FGV, C.115).

37 War Diary of XXXVIII. Army Corps, entry from 2 December 1941 (BA-MA, RH 24-38/51).

38 Tätigkeitsbericht der Abt. III des Gen.Kommandos des XXXVIII A. K. für die Zeit vom 11.XI.1941 bis 31.III.1942 (BA-MA, RH 24-38/253).

39 Kilian, Wehrmacht, pp. 225-33. In fact, in the last three months of 1941, three pillaging cases not involving Spaniards were tried by the military court of the 16th German Army, along with nine others for 'crimes against property'. See Armeegericht (military court) records of the 16th Army for 16 October to 21 December 1941, dated 19 January 1942 (BAMA, RH 20-16/1026).

40 José Cogollos Vicens, ¿Por qué? Y ¿para qué? (Valencia, 1985), p. 115; G. Hernanz Blanco, Diario de Guillermo en Rusia, 1942 (Salamanca, 2013), p. 220, entry from 6 October 1942.

41 Fernando Torres, 'Bombardeo de San Petersburgo', ABC, 4 June 1943; Emilio EstebanInfantes, La División Azul: Donde Asia empieza (Barcelona, 1956), p. 128. 
the civilian mortality rate increased eleven-fold in April 1942. Captain Serafín Pardo described months later how children and women would fight over the scraps the divisionarios gave them. ${ }^{42}$ When military surgeon Manuel de Cárdenas passed through the town of Gatchina, he wrote in his war diary of the malnourishment with clinical precision:

There are lots of people on the streets ...; old, bearded mujiks, dirty and ragged; shabby old women with faces yellowed from many months of hunger. Pretty young women nonetheless poor and dirty; not as thin as the old women as they can work some and are better suited to finding food thanks to their youth. Barefoot urchins with hats on their heads but so horribly thin their legs look like they belong to skeletons ... The hunger among these civilians is honestly frightening. They may not even survive the next winter. I often see men with juvenile features but who look so horribly aged, paled by avitaminosis and their legs swollen from hunger. And these half-men are the lucky ones, they are not in the prisoner camp. ${ }^{43}$

The civilians were so underfed that malnutrition weakened their immune systems and aggravated their illnesses. They lacked adequate medical attention. Spanish doctors in the immediate rearguard often helped the civilian population, ${ }^{44}$ but their good intentions were not always enough. In June 1942, Cárdenas visited a hospital for civilians and Soviet prisoners in Kolmovo, ${ }^{45}$ and what he saw horrified him: 'The civilian population ... survived this winter and now suffer from the most awful hunger and misery.' The hospital environment was frighteningly gruesome: 'It smells so incredibly bad ... Each body is more emaciated than the last; their faces, hands and feet look like anatomical illustrations, where even the smallest tendon can be seen.' 46

Despite occasional plundering, since the beginning of 1942 the Spanish soldiers were generally amicable to the civilian population. Orders from BD headquarters required the correct treatment of prisoners and civilians, but also warned of the dangers of excessive fraternization. In May 1943, Esteban-Infantes instructed the Division command to be wary of soldiers or officers living with women or Russian families outside Division protocol, but their responses showed little concern for this issue. ${ }^{47}$

42 Monthly report of the Wirtschaftskommando Krasnogwardeisk for April 1942 (BA-MA, RH 20-18/1358); Serafín Pardo Martínez, Un año en la División Azul (Valladolid, 2005), p. 118.

43 Military Surgeon Manuel de Cárdenas, Diario, entry from 1 September 1942 (personal archive of Mr José M. de Cárdenas, San Sebastián).

44 See for example the evocation of the services rendered by Spanish military surgeons in J. Santamaría Díez, 'Sdrinoga', Blau División, 179 (June 1974) and idem, 'Anecdotario del Doctor Payno’, Blau División, 180 (July 1974); Juan Pablo D’Ors Pérez, Diario de un médico español en Rusia (Madrid, 1960).

45 The hospital perimeter had been secured to prevent psychiatric patients from circulating in areas adjacent to Novgorod, where the civilian population had been evacuated by order of the commander of the 38th Army Corps on 31 December 1941 (BA-MA, RH 24-38/34).

46 Cárdenas, Diario, entry from 3 June 1942.

47 See General Instruction 2.016, 4 May 1942 (AGMAV, 28/28/18); for the written responses of officers to the memo of General Esteban-Infantes dated 27 May 1943, see AGMAV, $2007 / 12 / 2 / 5$. 
Yet, for many Russian women, children, and elderly, having an officer in the house with his assistants, or a squadron of soldiers, could be a lifeline for survival, giving them access to extra rations and clothing as well as protection against possible abuse from other soldiers. Generally, two months after their arrival at the front, the Spaniards were more welcome than the Germans, as they tended not to force the elderly to clear roads and let the peasants use their livestock for ploughing when the ground thawed. The Iberians often found in Russian peasant women 'the family we lacked because it was far away', while Spanish lodgers were seen as protection against the greater rigours of German occupation. ${ }^{48}$ However, Spaniards also became aware of the misery their 'adoptive' families suffered. Salvador Zanón noted in December 1941 that the hungry family of the isba (farmhouse) where his platoon lived also had to feed them:

Craba lives with her small, dirty, crying son, two very ugly women and two other lads of eight or ten years, who teach us Russian and eat the candy and chocolate we supply. These poor people live a sad, harsh life, but where else can they go? Here at least they have a few potatoes, well hidden so that we do not take them. ${ }^{49}$

Spanish officers were particularly welcome, as they brought with them better supplies. Vasíly P., a 13-year-old boy at the time, was lucky enough to have a Spanish lieutenant living with him and his mother. The officer put a guard at the door and received additional food supplies. He shared the food with the Russian family, as did many divisionarios..$^{50}$ Other testimonies support this image. Ochapkina A. Dimitrieva remembered the Spanish soldiers' good behaviour towards the peasant families taking refuge in the Otenskij monastery: 'they were more human than the Germans'. ${ }^{1}$ According to the young collaborator Lidia Ósipova, in Pavlovsk the locals' first impression of the exotic occupiers was ambivalent: 'These Spaniards destroyed the image we had of their people as proud, noble, beautiful, etc. ... They are small and unruly like monkeys; dirty swindlers like gypsies'; but also 'very kind'. Certainly, the success of the Iberian volunteers was not entirely due to their southern charm; from mid-1942, they often received packages from Spain, which contained products impossible to find in Russia, from chickpeas to liquor. They often distributed their surplus among the local people. Naturally, this endeared them to the civilians, who took to them, 'as they had never been fond of the Germans'. On 17 September 1942, Lidia recorded that a Spanish captain had risked his life to save a homeless child during a bombardment. A few days later, BD soldiers wept

48 Guillermo Díaz del Río, Los zapadores de la División Azul. Rusia 1941-1942 (Madrid, 2011), pp. 202-3; testimony of Antonio Vallejo Zaldo, in Pablo Larraz and Vicente SierraSesúmaga, Requetés. De las trincheras al olvido (Madrid, 2010), p. 373.

49 'Diario de la campaña de Salvador Zanón Mercado (V ${ }^{a}$ Parte)', Blau División, 623 (June 2011), entry from 22 December 1941.

50 Interview with Vasíly P. (born 1928), Podberesje, 29 April 2003 (author's personal archive, AA). See also the testimony of Vera (born 1926), a peasant girl from Trubitchino, in Fernando Garrido Polonio and Miguel A. Garrido Polonio, Nieve Roja. Españoles desaparecidos en el frente ruso (Madrid, 2002), pp. 90-1.

51 Testimony in Kovalev, Dobrovol'cí, pp. 330-2. 
inconsolably at the funeral of a Russian girl hit by a bullet. On the downside, the organizational chaos that reigned in the Iberian rearguard created uncertainty among the civilians as to what was and was not allowed. Unlike the Germans, the Spaniards tended to be unpredictable. ${ }^{52}$

However, the requisitions did not end when the BD was transferred to Leningrad's southern flank. The peasants occasionally reported these events to Spanish officers, and in several cases forceful occupation and ransacking of homes by soldiers led to a council of war. ${ }^{53} \mathrm{~A}$ German lieutenant wrote in September 1942, 'Whether they are German or Spanish, the soldiers who risk their lives in the vanguard do not ask themselves if the Muschik goes hungry in winter, they simply take the potatoes from the ground.' The Iberians were particularly unsystematic in pillaging. This caused trouble for the German command as the peasants, protesting the Spanish plundering, also pillaged everything they could find. The German officer wondered if they 'should hang a couple [of peasants] as an example'. ${ }^{54}$

The adverse effects of thefts and requisitions on the image of the divisionarios among the Russian peasants were not always compensated for by equivalent acts of kindness by other soldiers and officers. As with other Wehrmacht divisions, experiences varied greatly among units and villages. When Captain De Andrés's detachment passed through Viriza, they found a group of famished elderly persons and children whose chickens had been stolen by another Spanish unit. To repair this deed, De Andrés sacrificed a horse and distributed it among them. When Captain Serafín Pardo arrived at his new post on the Leningrad Front, he took in a starving Russian family to work as auxiliaries for the soldiers in exchange for ample rations. The son of that family returned to Spain with the divisionarios and became an engineer. ${ }^{55}$

\section{Ugly Panienkas and Idealized Katiuskas}

From the very beginning of the Spanish occupation, plenty of romances occurred between divisionarios and panienkas, the Polish word for girls that the Iberian volunteers also extended to Russian women. Numerous orders were issued from the BD General Staff prohibiting close relationships between Russian civilians and soldiers, which extended to dancing, walking arm in arm with 'Soviet women', knocking at their doors, and accepting their invitations. ${ }^{56}$ The frequent reiteration of these instructions speaks of their

52 Diary of Lidia Ósipova, entries dated 25 August, 17 September, 30 September, 1 October, and 5 October 1942, reproduced in Nikita Lomagin, Neizvéstnaya blocada (St Petersburg, 2004), vol. II, pp. 464-6.

53 This occurred a few months after the BD arrived in Pavlosk, when a group of seven soldiers entered the lodgings of Russian civilian Catarina Malischewa. The accused were condemned to six months' incarceration (AGMAV, C. 3777/2). The same happened in the isba of Serafina Sukolova (AGMAV, C.3800/9).

54 Letter from Lieutenant P. Emerich, Ortskommandantur II (351), 22 September 1942 (Bibliothek für Zeitgeschichte, Stuttgart, Sammlung Sterz).

55 Antonio de Andrés, Artillería en la División Azul (Krasny Bor) (Madrid, 2004), p. 25; Pardo Martínez, Un año, p. 118.

56 General Instruction 2016, 4 May 1942, regarding fraternizing with Russian women (AGMAV 28/28/18/3). 
ineffectiveness, as does the lack of interest in enforcing them on the part of officers. ${ }^{57}$ Many a Spanish volunteer maintained virtually platonic relations with young women they could barely communicate with through gestures. Soldier Roberto Rivera described in August 1942 how 'My dear little friend Tatiana (19 years old) tries to teach me to speak Russian ... Until now I have only learned to say jorasó = pretty and lin-blin = I love you. ${ }^{58}$ Spanish soldiers portrayed themselves in the Hoja de Campaña (BD trench journal) as surrounded by doting women who washed their clothes 'because I give them sweets in exchange'.

Though gallantry with Russian women was more intense on the Leningrad Front than the Volkhov Front, ${ }^{59}$ matches between the occupying soldiers and Russian women were plausible in the shared living conditions that prevailed on both areas. It was not limited to the Spanish either; even the supposedly cold Germans fancied Russian women. The sexual relations between the occupiers and Slavic women were far more commonplace than either side cared to acknowledge. ${ }^{60}$ However, Spanish soldiers' romances with Russian women sometimes ended up in unauthorized weddings, and by mid-1942 the situation was scandalizing a Wehrmacht High Command that was only willing to recognize marriages with Baltic women. The BD command decided not to officially validate any matrimoniies between divisionarios and Russian women, forbidding that they be taken to Spain when the soldiers returned. ${ }^{61}$ However, some of these marriages served to hide a different type of relationship. For example, Colonel Robles Pazos ordered his Russian lover to marry one of the Division's Russian interpreters so he could bring her back to Spain. ${ }^{62}$

Though some marriages occurred, very few sincere relationships emerged out of these circumstances. For a start, the Russian women encountered were quite removed from the feminine ideal held by the Iberians, especially those from urban, middle-class backgrounds.

57 In October 1943 a similar instruction outlined the same terms (GS Order 1 February 1943, AGMAV, 28/29/11/7). More examples in Bowen, Spaniards and Nazi Germany, pp. 114-15.

58 Letter from soldier Roberto Rivero to Carmen Sánchez, 26 August 1942, in Manuel de Ramón and Carmen Ortiz, Madrina de guerra. Cartas desde el frente (Madrid, 2003), pp. $355-6$.

59 'Carta guripal', Hoja de Campaña, 69, 30 May 1943; Benigno Cabo, Diario de guerra, pp. 128-9; Dionisio García-Izquierdo, El último divisionario en Possad. Batallón de Transmisiones en la División Azul (Granada, 2009), pp. 333-5.

60 Juan Chicharro Lamamié de Clairac, Diario de un antitanquista en la División Azul (Madrid, 2001), p. 42. Love between Eastern Front soldiers and Soviet women normaly had one real function: to find an illusory refuge from the hardships of war: see Stephen Fritz, Frontsoldaten. The German Soldier in World War II (Lexington, 1995), pp. 78-9; Jeff Rutherford, Combat and Genocide on the Eastern Front: The German Infantry's War, 1941-1944 (Cambridge, 2014), pp. 166-7; and Regina Mühlhäuser, Eroberungen: Sexuelle Gewalttaten und intime Beziehungen deutscher Soldaten in der Sowjetunion 1941-1945 (Hamburg, 2010), pp. 159, 216.

61 OKH to Army Group North, 20 May 1942, and 18th Army to Army Group North, 12 June 1942 (BA-MA, RH 19III/ 493). See also José M. Trepat Padró, 'Carta a los dieciséis años de un español en Rusia', Hermandad, III:8 (1959).

62 Pardo Martínez, Un año, p. 133; Palacio Pilacés, Tal vez el día, vol. I, p. 552. 
Even when they could find Russian women with urban habits, such as in Minsk, their feelings were fairly similar. Private Ramírez Morales described it as 'looking through an old photo album from the 1920s'. ${ }^{63}$ Letters and diaries portrayed Russian country girls as females lacking graces, dirty and unkempt, aged by work, hunger and misery, dressed in rags and not always given to respecting traditional morals. A far cry from the feminine ideal cherished by Spanish men, especially those from the urban middle class. ${ }^{64}$ Private Martínez Tessier noted the want of delicacy of form, distinction of dress, and silk stockings in the first Russian peasant girls he saw: 'The women have no femininity. ... Their manners are also manly.' ${ }^{65}$ Another volunteer of middle-class background wrote that 'the woman, in Russia ... lacks the most exquisite sense: femininity. She is a bear that works the fields.' ${ }^{\prime} 6$

The distance between Russian peasant women and the aesthetic ideals for Spanish women - or European urban middle-class women in general - was not only a consequence of war privation and German occupation. ${ }^{67}$ It was understood as one more example of Soviet barbarism, a male monster that had supposedly stripped women of all feminine and moral content in order to facilitate the destruction of traditional family ties. Their lack of hygiene also fit with the dirtiness of the Russian context. Lieutenant Arenales noted how only female teachers were worthy of interest, 'since they seem to wash, which is uncommon'. The pseudo-oriental physical features he thought he saw in them were also considered less attractive: 'small, slanted eyes that seem sunken due to exaggerated cheekbones'. 68

Not everything qualified as the naïve love or idealized respect for peasants that was later published in the memoirs of Spanish veterans. ${ }^{69}$ Often, the objective was mere sexual entertainment with peasant women, who were seen as primitives who might lack morals and welcome promiscuity. In October 1941, several Spanish soldiers entered a house in Podberesje, looking for a sergeant and a corporal who were missing from their unit. There they witnessed how their comrades made love to (or raped?) some Russian women with oriental features in a dirty, promiscuous environment, according to the war diary of one of them:

63 Diego Ramírez Morales, 'Notas de un diario', Juventud, 29, 5 November 1942.

64 Raimundo Sánchez to Joaquina Cabero, 18 January 1943 (Museo del Pueblo de Asturias, Gijón, R.6410, 16/15-3). See also M. Salvador Gironés, 'Cosas de por allá', Blau División, 85 (September 1966).

65 Jesús Martínez Tessier, Diario, entry from 14 September 1941 (personal archive of J. Martínez Reverte, Madrid).

66 'Cartas de Rusia', Boletín del SEU de Madrid, 11 (1942).

67 As reflected in the testimonies of the Russian peasant girls themselves: see Rebrova, 'Überlebensstrategien', pp. 290-1.

68 Benjamín de Arenales, Diario de Operaciones e impresiones, entry dated 5 June 1942 (personal archive of Mr Carmelo de las Heras, Madrid); Enrique Errando Vilar, Campaña de invierno (Madrid, 1942), pp. 169, 250.

69 As an example, see the unpublished novel Recuerdos by the volunteer Óscar Rey, which narrates a story of love and jealousy between two BD soldiers and a Russian girl (personal archive of Mr Carlos Rey, A Coruña). 
There were two rooms ... and they smelled disgusting, in one were the 'fathers' and the 'children' of the femmes fatales, not at all concerned with the shrieks or with what their daughters or sisters were doing ... and in the other, unbelievably, none other than the sergeant and the corporal, talking little and doing much, with two Spaniards and two Germans sitting there drinking and singing and 'admiring' the Russian beauties. You should have seen them! And especially - what a fright - two of them were short, stout, with slanted eyes, mongoloid lips and repugnant arms ... one was missing half a nose and half of her face was burned, and the other kept farting so much that it turned my stomach ... ${ }^{70}$

The ironic farewell letter of a contributor to the Hoja de Campaña in March of 1944 demonstrated a tone quite removed from Don Juan gallantry. He suggested that his panienka should continue to cultivate the barley and alfalfa; he begged her too to remain true to 'himself, Perez, Sergeant Gomez and Corporal Ortiz'. ${ }^{71}$ Blatant prostitution also occurred. One teacher from Samokrasa, finding she could no longer impart lessons, earned a living for herself and the children by 'selling herself as a prostitute to the Spaniards who occupied the school complex'. ${ }^{72}$ Some diaries suggest that other panienkas offered their charms in exchange for food, and relationships could also blossom from such encounters. Near Sitno in early December, one logistics soldier visited 'some panienkas that I was told were quite nice looking. They laughed and "we had fun".' He visited one of them several more days. When his unit was forced to withdraw, she asked in vain that he take her with him. $^{73}$

Corporal Antonio Herrero wrote in April 1943 that after attending the Catholic mass, the soldiers in his company attended a 'magnificent banquet followed by a fun dance with the local girls'. Evening parties were common in spring and summer, often in front of an Orthodox church that had been reopened by the occupying forces. ${ }^{74}$ However, some testimonies suggest that many of these fetes were organized by the German Kommandaturen, which recruited local women with food. One Russian interpreter indicated in letters to Spain that his main duties involved travelling in the rearguard seeking girls for the officers' parties. ${ }^{75}$ Relations with Russian women implied a mix of seduction and distrust, gallantry and fear: they might be collaborating as decoys for a partisan

70 Anonymous, 'Diario de un Soldado' (AGMAV 46767/2/5), entry from 28 October 1941.

71 El Gafas de la Tercera, 'Carta a mi pañenka', Hoja de Campaña, 105, 11 March 1944.

72 J. Santamaría Díez, 'Anecdotario del Dr. Payno', Blau División, 183 (October 1974).

73 'Diario de un Soldado', entries from 2, 3, and 8 December 1941. Such conduct was also common among German soldiers (Rutherford, Combat and Genocide, pp. 187-9; Mühlhäuser, Eroberungen, pp. 251-2).

74 Letter from Antonio Herrero to his mother, 25 April 1943 (AA); Cárdenas, Diario, entry from 20 May 1942; Víctor J. Jiménez Malo de Molina, De España a Rusia. 5.000 kilómetros con la División Azul (Madrid, 1943), p. 176; interview of the Orthodox priest of Koritsko, 27 February 2015 (AA).

75 Pardo Martínez, Un año, pp. 123; note of the Dirección General de Seguridad, 9 December 1941 (AHMC-FGV, C. 115). Some Russian mothers hid their daughters from the Spanish officials (Kovalev, Dobrovol'cí, p. 365). 
ambush at the party. ${ }^{76}$ Additionally, the daily disputes between German and Spanish soldiers often revolved around food, the black market, or women. Many German soldiers and Germanic Waffen SS volunteers, disregarded the racial dictum prohibiting sexual relations with female Soviet civilians. Antonina Davychenko (born 1932) wrote of a fistfight that occurred when Spanish soldiers protected a Russian woman from the harassments of German soldiers. Lidia Osípova indicated that when the Iberians arrived in Pavlovsk, 'all the loose women who were with the Germans immediately went to be with the Spaniards', attracted by their gregarious Latin nature and their better food rations. Russian women also regarded them as better lovers. ${ }^{77}$

Children constituted a very different chapter in the narrative, as creatures whose innocence could easily symbolize and reinforce the re-Christianizing mission Spaniards attributed to themselves. ${ }^{78}$ Many volunteers saw themselves as protectors of children, and gave them treats and food. Many were taught to pray or speak a few words in Spanish. ${ }^{79}$ Compassion for the children in their misery showed up in testimonies. Martín Velasco wrote of the hunger in Vitebsk:

Four Russian children near me are holding in their little hands a greasy paper with lamb bones from our mess, which the cooks gave them. It is pitiful and sad to see how these children peel bones with almost no meat on them and look at me with small sad eyes, saying gout [sic], which in German means 'good'. 80

Many Spanish veterans described having nourished and protected little children - virtually adopting them - as their best memory of Russia. The later accounts of elderly peasants from the Novgorod area corroborate this. Unlike the Germans, Spanish soldiers were often surrounded by children. ${ }^{81}$ Many of these malenkis were war orphans who sometimes formed bands that wandered about the rearguard searching for food or shelter,

76 Manuel Álvarez de Sotomayor, Generación puente (Alicante, 1991), pp. 162-3; Rodrigo Royo, El sol y la nieve (Madrid, 1956), pp. 88-9; José García Luna, Las cartas del Sargento Basilio (Barcelona, 1959), pp. 32, 113; García-Izquierdo, El último, pp. 336-7; Juan J. Sanz Jarque, Alas de águila. La División Azul en Rusia (Madrid, 2010), p. 330; Angel Ruiz Ayúcar, La Rusia que yo conoci (Madrid, 1981), pp. 41-51.

77 Testimony of Antonina Davychenko, reproduced in the documentary from Saint Petersburg local TV, The Siege of Leningrad (2007); Diary of Lidia Ósipova, entries dated 25 August and 5 October 1942 (Lomagin, Neizvéstnaya, vol. II, pp. 464-6).

78 'Al amparo paterno', Hoja de Campaña, 80, 15 August 1944; José Martialay, 'Nueva primavera', Nueva Alcarria, 23 May 1942.

79 Moisés Puente, Yo, muerto en Rusia (Memorias del alférez Ocañas) (Madrid, 1954), pp. 157-8; Dionisio Ridruejo, Cuadernos de Rusia (Barcelona, 1978), p. 283; Pablo Castelo Villaoz, URSS: un rayo de luz y esperanza (Alicante, 1992), pp. 13-14; José Martialay, 'Horas y horas en el descanso', Nueva Alcarria, 7 March 1942.

80 War Diary of private Martín Velasco, entry from 3 October 1941 (personal archive of Mr. Pablo Velasco, Toledo).

81 Interviews with Lidia Nikolaevna Yerofejeva, Possad, 27 February 2015, and the priest of Koritsko, 27 February 2015 (AA); more testimonies in Kovalev, Dobrovol'cí, pp. 336, $372-3$. 
begging or engaging in petty theft. ${ }^{82}$ A Falangist veteran described his best memory from the Russian Front: 'Lyda Kakuska Sylgueida, 12 years old, blonde as a peach. Her face was rosy, she was a thin, angelical little creature. ... She ate with us, displaying extreme tenderness and delicacy ... Sad smile. She never spoke of her parents.' BD troops frequently supported orphans or the children of widows; occasionally, sexual favours from the mothers were implicitly acknowledged as the price for such altruistic protection. ${ }^{83} \mathrm{In}$ spite of the Franco regime's zeal to avoid infiltration by Soviet spies, several documented cases tell of Russian children and adolescents hiding in wagons or dressing as divisionarios and being taken to Spain by Spanish soldiers and officers, who then incorporated them into their families. ${ }^{84}$ This also constituted a clear difference from the attitudes of German soldiers.

\section{Dealing with Partisans: Benevolence or Inefficacy?}

Anti-guerrilla operations and the treatment of captured Soviet partisans are among the thorniest issues in the post-1945 narratives of Spanish veterans. Problematic from the moment the Blue Division entered Soviet territory in September 1941, partisans were responsible for a significant number of Spanish casualties. However, war veterans' memoirs generally recalled that burnt Russian villages and hanged peasants were always the work of the German allies. ${ }^{85}$ To avoid poisoning by the enemy, the BD command instructed in October 1941 that it was best to have peasants or Russian prisoners drink up to 1.5 litres of water before it was declared potable. During the march through occupied territories, members of the first expedition witnessed German reprisals against partisans or suspects. In their diaries, several Iberian soldiers wrote of seeing partisans - and civilians accused of collaborating with them - being shot. ${ }^{86}$ They also saw partisans hung in town squares as a warning to the civilian population. Some equated partisans with Jews, based on a characteristic slogan of Wehrmacht propaganda. ${ }^{87}$

82 See for example Julio R. Montes, El búnker (Barcelona, 2006), pp. 93-6, 113-17. Regarding the abundance of orphans in the rearguard, see the report of the Wirtschaftskommando Krasnogwardeisk, 20 April 1942 (BA-MA, RH 20-18/1358).

83 See the watercolour by the Spanish cartoonist of the BD trench journal Joaquín Alba 'Kin' Sana alegría de los niños (Archivo General de la Administración, Alcalá de Henares, F/0474); Blau División, 50 (October 1963).

84 See for example three cases in José M. Puente Fernández, Cántabros en la División Azul (1941-1944) (Torrelavega, 2012), pp. 125-8. Most were intercepted by the German military police.

85 Carlos M. Ydígoras, Algunos no hemos muerto (Madrid, 1984 [1957]), pp. 26, 53, 59-60, 68-9, 71-3.

86 DEV, 2nd section, 17 October 1941 (AGMAV 3736/5); testimonies of Juan Luis Pacheco, Francisco Tarrés, Pedro Bejarano, Adolfo de Montagut and Guillermo González de Canales, numbered in Pablo Sagarra, Capellanes en la División Azul. Los últimos cruzados (Madrid, 2012), pp. 643-4; Luis Aguilar, 'Diario de mi Campaña de Rusia (3 ${ }^{\mathrm{a}}$ parte)', Blau División, 603 (2009), entry from 18 September 1941; Alfonso de Urquijo, Cuando empuñamos las armas. La pequeña historia de una familia numerosa entre 1936 y 1942 (Madrid, 1973), p. 272.

87 Martínez Tessier, Diario, entry dated 28 September 1941. 
These scenes multiplied proportionally when Spanish volunteers reached the Volkhov Front in October 1941 and during the subsequent offensive. Víctor J. Jiménez described in 1943 how his literary alter-ego, an artillery officer, was ordered by the Germans to execute two partisan commanders the very day he arrived at the front line. ${ }^{88}$ The Information Section of the Blue Division interrogated dozens of prisoners to identify political commissars and possible partisans. They were then sent to the German Army Corps Headquarters and most likely shot. ${ }^{89}$

The divisionarios perceived partisan danger as a diffuse, omnipresent threat: like 'ghosts' who populated the dense forests, which 'were infested with Russians. Bands of them fight with the support of the civilian population. We hear news of betrayals, ambushes, and then reprisals. It is common to see someone from the towns on the banks of the Volkhov hanging from a beam or telephone post. ${ }^{90}$ By early 1942 nearly 20,000 Soviet partisans operated in the rearguard of the Army Group North and were particularly abundant in the Novgorod region. However, the level of partisan activity was moderate, at least compared to White Russia or Ukraine. ${ }^{91}$ The command of the Army Group North rearguard took less aggressive measures to combat partisans and used propaganda to encourage peasant cooperation or the surrender of guerrilla members. Reprisals and firing squads intensified after mid-1942,92 and the bulk of partisan activity occurred in the far rearguard, the rückwartiges Heeresgebiet, where no Spanish soldiers were deployed. Other foreign units, such as the Hungarians in the rear of the Army Group Centre, were systematically deployed to combat partisans. These units frequently employed a high level of violence, stimulated by fear and the brutalization of their fighting environment. Spaniards, in contrast, were never called upon by the German Command to carry out this kind of task. ${ }^{93}$

In October 1941, instructions from the BD High Command broadly recommended that if 'any individuals of the opposing army, in isolation or in groups', were caught 'carrying out acts of sabotage such as blowing up bridges, assaulting vehicles or lodgings, or carrying out guerrilla warfare dressed as civilians', the officers in charge were authorized

88 Jiménez Malo de Molina, De España a Rusia, pp. 178-9, 187-8.

89 Fernando Vadillo, Orillas del Volchov (Madrid, 1967), pp. 347-53.

90 See José M. Sánchez Diana, Cabeza de puente. Diario de un soldado de Hitler (Granada, 1993), p. 132.

91 Regarding the Red Army's use of guerrilla warfare, see Kenneth Slepyan, Stalin's Guerrillas: Soviet Partisans in World War II (Lawrence, 2006) and Alexander Hill, The War behind the Eastern Front: Soviet Partisans in North-West Russia, 1941-1944 (London, 2005). By the end of 1944, the USSR had mobilized some 300,000 partisans, many of which were army units infiltrated in the German rearguard. The expansion of partisan groups became increasingly problematic for the Wehrmacht, even on the Northern Front, from 1942 onwards.

92 See Hasenclever, Wehrmacht, pp. 371-7, 410-17, 448-55; Rutherford, Combat and Genocide, pp. 145, 215.

93 Some attributed it to the lack of a mounted section (cavalry) in the BD, which had been replaced with a bicycle section that could not carry out its duties in forested or marshy areas. See the IC section report of the XXXVIII Army Corps regarding Partisanenlage beim XXXVIII. A. K., 13 July 1942 (BA-MA, RH 24-38/164); José Martínez Esparza, 'Los “partisanes” y otros rusos', Hoja de Campaña, 97, 15 December 1943. 
to do 'whatever needs to be done with these individuals, depending on the tactical situation'. Eleven days later, a new instruction indicated that in light of the increasing intensity of guerrilla activity, sector chiefs and officers who caught partisans should assume guilt and not seek conclusive evidence, which might have been destroyed 'with the possible complicity of the locals'. Officers must not be 'lenient with the resulting threat to the security of the area entrusted to us'. Suspicious individuals should be handed over to the closest German command and 'snipers' should be hanged in a public place after interrogation and remain visible for several days as a warning. ${ }^{94}$ These guidelines were softened in mid-1942, instructing that partisans who surrendered be given the same treatment as Red Army deserters. In theory, Spaniards were to hand over all punishable cases and summary procedures against prisoners of war were to be carried out by the closest German military authorities. The few testimonies that mention retaliatory operations indicate that locals were always handed over to the Germans, who also carried out massive reprisals in towns where sentries had been murdered. There is evidence that Iberian soldiers handed over escaped prisoners to the competent authorities in the 16th and 18th Armies. ${ }^{95}$

In early 1942, the German command decided to relieve the Blue Division of all sentry duties in the near rearguard, partly because the Spaniards had to cover a very broad section of the front. ${ }^{96}$ Where they were responsible for these duties, evidence suggests that control of the civil population was less brutal and thorough than with the Germans and the 'security divisions' and 'protection teams' (Sicherungsdivisionen and Schutzmannschaften) that operated in the rear. The Iberians maintained practices reminiscent of those used in the former colonial wars, rather than the brutalized and radical 'totalitarian counter-insurgence' methods of the Wehrmacht. ${ }^{97}$ Spanish efficacy in the anti-partisan fight was also dubious: their evacuations of the civil population from towns were often chaotic, without 'any military supervision whatsoever' and without the authorization of the Division High Command. This might facilitate Soviet espionage and favour the partisans. In July 1943, cases of Spanish soldiers losing their documentation and weapons to Russian civilians prompted the command of Army Corps L to recommend that the Spaniards exercise stricter control over the population. ${ }^{98}$

In May 1943, increased partisan activity led the XXXVIII Army Corps command to involve the divisions on the front in the persecution of partisans operating in their

94 General Instruction 2007, 17 October 1941 and 2007B, 28 October 1941 (AGMAV, 2005/5/5).

95 General Instruction 2023, 7 July 1942 (AGMAV, 2006/1/1/7); OKW order from 20 August 1941 (BA-MA, RW 19/686). Testimony of one such reprisal was narrated by repatriated soldiers in a Spanish police report, San Sebastián, 30 January 1942 (AHMC-FGV, C.115); Tätigkeitsbericht der Abt. Ic/A. O. für die Zeit von 1. bis 22 November 1941 (BA-MA, RH 20-16/473).

96 Instruction of the High Command of the XXXVIII Army Corps, 5 January 1942 (BA-MA, RH.24-38/34).

97 For a comparative discussion, see Beatrice Heuser, Rebellen-Partisanen-Guerilleros. Asymmetrische Kriege von der Antike bis heute (Paderborn, 2013), pp. 142-215.

98 Pioneers' Battalion 250 to the captain of the 1st Company, 5 October 1942 (AGMAV 1985/3/5/1); Army Corps L, Order dated 10 July 1943 (BA-MA, RH 24-50/66). 
respective rearguards. Thus, the Spaniards were required to work with detachments of auxiliary Russian and Baltic troops. Some testimonies corroborate that the BD command had given orders to their units to execute any captured partisans on site. In October, instructions from Army Corps L indicated reprisals against local civilians were to be carried out wherever Wehrmacht soldiers had been attacked. However, Spanish efficacy in controlling partisans and civilians acting as informants did not improve. On 18 July 1943, the Blue Division headquarters in Pokrovskaia suffered a precise Soviet artillery attack due to information provided by spies infiltrated among Russian assistants to the BD. ${ }^{99}$ Four months later, the German command learned of the presence of a group of partisans to the south of Nikolawja and requested the assistance of 200 Spanish soldiers in 'cleansing' the area. However, the operation failed for lack of efficiency among the Spaniards. German officers blamed the botched operation on their allies' repeated indiscretions with their Russian aides, who then passed on the information to partisans. ${ }^{100}$

Few BD internal reports mention explicit anti-partisan actions or their results, but the exceptions show that they did occur. ${ }^{101}$ Spanish testimonies tend not to clarify who shot the partisans and provide few details regarding reprisals. Several BD deserters interrogated by the Red Army by the end of 1942 admitted hearing stories of reprisals against partisans from their German comrades, but said they had never actually seen any. ${ }^{102}$ Other testimonies allude to German soldiers and medics 'finishing off' injured partisans or regular soldiers, as well as prisoners. However, the Germans did not act alone: some divisionarios stated that they were ordered to execute those who had been arrested and summarily tried. ${ }^{103}$ Captain De Andrés recalled with disgust his interrogations of several civilians over the suspected disappearance of one of his men: 'for the first time, I acted as a German oppressor'. Yet, several testimonies alleged that the partisans 'respected' the Spaniards more than they did the Germans. ${ }^{104}$

99 Juan S. Muñoz Césaro, Yo fui legionario de Europa (Salobreña, 2011), pp. 158, 183 (entries from 29 May and 31 October 1943); Rodríguez Jiménez, De héroes e indeseables, p. 232; Gerald R. Kleinfeld and L.A. Tambs, La División española de Hitler (Madrid, 1983), pp. 470-1; 'Los que no volvieron. Prisioneros españoles en Rusia', El Español, 14 November 1953.

100 Report by Obersturmführer Vey to Einsatzkommando 1, 6 November 1943 (United States Holocaust Memorial Museum, Washington, Archive Collection, Sp BD 11.001M.05).

101 Daily report of 250th Division to the XXXVIII Army Corps, 18 December 1941 (BA-MA, RH 24-38/171).

102 Interrogations of a Spanish soldier of the 10th Company, Regiment 269, who went over to the Soviets on 2 December 1942; of a soldier of the 3rd Company of the same regiment who deserted 8 November 1942 and another of the Reconnaissance Battalion: Gatchina Naval Archive, 102.o.1.d.354.11.71-4, 110-13, 146-9.

103 Testimony of Anselmo Pérez Gómez, in Anselmo Pérez Maestre, La División Azul de Huelva, 1941-1943 (Huelva, 2008), pp. 161-3; Sanz Jarque, Alas de águila, p. 239; Diary of private Pedro Solé Castelló, entry from 25 March 1942 (http://www.miabueloenrusia. com, accessed 5 December 2012).

104 D’Ors Pérez, Diario, n.p.; Ramón Farré Palaus, Impresiones. Centinela junto al Ilmen (Alicante, 1991), pp. 25-7; De Andrés, Artillería, pp. 128-9; Juan E. Blanco, Rusia no es cuestión de un día (Madrid, 1954), p. 58; Fernando Vadillo, Balada final de la División Azul: Los legionarios (Madrid, 1984), p. 48. 
The perspective of the Russian civilians suggests something similar. Spanish soldiers occasionally carried out reprisals against civilians when blinded by a desire to avenge the death of a comrade. Lidia Nikolaévna was 11 when her village of Rogavka, located in the rearguard, became the residence of several detachments of Spanish soldiers resting from combat in early December 1941. Partisan activity immediately increased, involving several Spanish victims. ${ }^{105}$ The Russian girl witnessed how the Spaniards rounded up all the inhabitants from the town and surrounding area to take revenge and hang a partisan fighter. In this case, the local German commander impeded greater reprisals, as the Wehrmacht needed the civilians for labour. The BD rearguard was no blissful Arcadia. ${ }^{106}$

\section{Brutalization, Indoctrination, or Exception?}

Assessments of the Spanish conduct on the Eastern Front should fall somewhere between the 'clean Blue Division' legend - as reproduced in the post-1945 narrative based on war veteran memoirs and in the more or less apologetic historical literature - and the general characteristics that apply to most German Wehrmacht troops, particularly in the northern sector of the Eastern Front. The Spanish 250th Division never had a central role in the War of Extermination unleashed by the Wehrmacht on the Eastern Front, nor are there indications that the Spanish commanders knew of the long-term occupation schemes of the Third Reich leaders, which were implemented by the military. Unlike Hungarian soldiers in the Ukraine and Romanian military police and combatants in Bessarabia, Bukovina, and Transnistria, Spaniards did not participate systematically, or specifically, in the rearguard in collective reprisals against Russian, Polish, Byelorussian, or Baltic civilians, or Jews. ${ }^{107}$ Moreover, Spanish troops were not affected by strong ideological or sociocultural factors. Certainly, some racialist undertones underpinned the Spaniards' perceptions of the Russian other, which they regarded as barbarian, Asiatic, and culturally inferior to 'civilized' Western cultures. In their view, this presumed cultural inferiority had paved the way for the success of Bolshevism, which could only flourish on fertile soil. Spanish racial views were not totally deprived of biological elements; yet, they were mostly shaped by historic, cultural, and geographical determinism. Since the mid-nineteenth

105 Daily Report of 250th Division to XXVIII Army Corps, 21 November 1941, 3 and 4 December 1941 (BA-MA, RH 24-38/171); see also the report of the 16th German Army Partisanenbekämpfung in der Armee in der Zeit vom 6-12 December 1941 (BA-MA, RH 20-16/99).

106 Interview of Lidia Nikolaévna, Rogavka, 28 March 2004 by Pavel Tendera (AA), and annex to the report of the 16th Army High Command to the IC department of Army Group North, 13 February 1942 (BA-MA, RH 20-16/99).

107 See Anderson, 'A Hungarian Vernichtungskrieg?'. Studies on the brutalization of Romanian warfare in the war against the Soviet Union mostly focus on its participation in the deportation of the Jewish and Gypsy populations of the 'reconquered' territories of Bukovina, Besarabia, and Transnistria. See Mariana Hausleitner, Brigitte Mihok, and Juliane Wetzel (eds), Rumänien und der Holocaust. Zu den Massenverbrechen in Transnistrien 1941-1944 (Berlin, 2001), as well as Armin Heinen, Rumänien, der Holocaust und die Logik der Gewalt (Munich, 2007), pp. 109-49, and Dennis Deletant, Hitler's Forgotten Ally: Ion Antonescu and His Regime Romania 1940-44 (Basingstoke, 2006), pp. 150-204. 
century, Spanish anthropologists considered their nation to be the outcome of a 'racial alloy', which had continuity in the American colonies. ${ }^{108}$ In this respect, Spanish perceptions of the East had more in common with German and Austrian perceptions of the Slavic enemy during the First World War. ${ }^{109}$ The Blue Division's trench journal recalled in October 1943 that race expressed 'a homeland based first on blood', but also on 'mixed blood ... From intense effusions of very diverse elements, Spain had forged its perennial racial basis.' Although Lenin and the Jews had erased 'whatever is noble in mankind' from the Russian people, the invaders would re-educate them and return the Russians to Christian faith. ${ }^{10}$ Most Spanish volunteers had not been socialized in biological racism (in relation to Slavs and Jews). The fighting environment at the Volkhov Front, and later in Leningrad, did not foster an accumulative radicalization of Spanish attitudes towards the enemy or civilians. The northern sector of the Eastern Front was more static than the centre and south, with less partisan activity. Spanish soldiers had not been fighting for months before they arrived on the front and stayed less time on average than their German comrades. These factors decisively enhanced the brutalization of the various Wehrmacht units, as has been demonstrated for the 121st, 123rd, and 126th German Divisions of the Army Group North. ${ }^{111}$ Their absence also conditioned the lack of steady brutalization of the Spanish Division.

Less certainty exists regarding other aspects, such as the treatment of prisoners and methods applied in the anti-partisan fight. ${ }^{112}$ General benevolence towards Soviet prisoners from December 1941 onwards was evident among Spaniards, but there were also summary executions and interrogations of prisoners in combat. Iberians were not especially effective, zealous, or cruel in reprisals and in the fight against partisans. They sometimes did execute civilians accused of hiding partisans. However, no evidence has been found to indicate they engaged in collective killings or reprisals against entire villages. German reports hardly mentioned Spanish participation in these activities. They do, however, reveal a certain lack of trust in Spaniards to carry out rearguard population

108 For the emergence and development of racial thought in Spain, see J. Goode, Impurity of Blood: Defining Race in Spain, 1870-1930 (Baton Rouge, 2007). On Spanish soldiers' racial and cultural prejudices towards Russia and the Russians on the Eastern front, see Xosé M. Núñez Seixas, 'Russia and the Russians in the Eyes of the Spanish Soldiers of the Blue Division (1941-44)', Journal of Contemporary History, 52.2 (2017), pp.352-74.

109 See Vejas G. Liulevicius, War Land on the Eastern Front: Culture, National Identity, and German Occupation in World War I (Cambridge, 2000), as well as Wolfram Dornik, “"Ganz in den Rahmen dieses Bildes passt auch die Bevölkerung”. Raumerfahrung und Raumwahrnehmung von österreichisch-ungarischen Soldaten an der Ostfront des Ersten Weltkrieges', in Bernd Bachinger and Wolfram Dornik (eds), Jenseits des Schützengrabens. Der Erste Weltkrieg im Osten: Erfahrung-Wahrnehmung-Kontext (Innsbruck, Vienna and Bozen, 2013), pp. 27-43.

110 'La raza', Hoja de Campaña, 88 (10 October 1943).

111 Rutherford, Combat and Genocide, pp. 115-52, 240-79.

112 Russian testimonies after 1944 only indicate that a Spanish lieutenant in Koritsko was responsible for some shootings of peasants suspected of collaborating with the partisans (Kovalev, Dobrovol'ci, p. 369). 
control and cleansing actions, given the demonstrated inefficacy of the Iberians in this area. The Blue Division's compliance with the Commissar Order also remains unclear. There is no mention of summary executions of Soviet commissars in Spanish memoirs and BD files. This does not necessarily mean it did not happen, since that order would have been transmitted verbally to Wehrmacht combatants.

The attitudes of Spaniards towards civilians were more ambivalent than later narratives suggest. Veteran Alberto Díaz expressed years later how Spaniards got along 'fairly well' with Russian civilians but 'whoever says the Russians were bad is lying and whoever says they were good is also lying and whoever says we Spaniards were saints lies too'; among the troops there were also 'louts, rogues, opportunists, even criminals'. ${ }^{113}$ The image of Russia and the Russians that Spanish officers and volunteers had, or forged at the front, did not include racial hatred and contempt based on biological-genetic tenets. However, diaries, letters, published articles, and caricatures in the Falangist press from that time show a much more nuanced picture than the idyllic, harmonious coexistence described in memoirs and writings published after 1945. The misery of the Russian peasants, their servile and submissive character, were understood as the consequence of communist degeneration, de-Christianization, and a supposed destruction of basic moral values such as respect for the family. Climate, culture, land, and centuries of non-European tradition were also perceived to be an influence. Russians were an Asian people: bloated, lacking spiritual personality, telluric, and primitive, with amoral tendencies that pre-disposed them to being the propitiatory victim of communism. ${ }^{114}$

This might be considered cultural racism, but it was not biological-genetic bigotry. It considered individuals to be determined by their cultural milieu, leaving little or no room for change. ${ }^{115}$ Often, this was subliminally expressed in tones redolent of social hygiene: frequent allusions to their dirtiness and lack of personal or family hygiene helped undermine consideration of Russians as human beings and transform political or social arguments into biological ones. Such a mindset also festered in Spanish fascism, which considered the occupied peoples as spiritually and culturally inferior or 'underage', though not as a biologically subhuman Untermensch. This peculiar vision of the enemy might incite commiseration and paternalism but never prevented Russian civilians from suffering requisitions and theft. Hierarchically uneven and logistically deficient troop provisioning was a factor from the moment the Spanish volunteers left their training camps in Germany. This was aggravated by organizational deficiencies and a lack of discipline among the BD troops, who were a heterogeneous mix of career officers, noncommissioned officers with little training, enthusiastic fascist volunteers, mercenary legionnaires, drafted soldiers who had been persuaded to go to Russia, adventurers, and,

113 Reproduced in Alfonso Domingo, Historia de los españoles en la II Guerra Mundial (Córdoba, 2009), p. 158.

114 Extensively on this, see Núñez Seixas, 'Russia and the Russians in the Eyes of the Spanish Soldiers', as well as idem, Die spanische Blaue Division, pp. 222-47.

115 See Michel Wievorka, Le racisme: Une introduction (Paris, 1998), pp. 42-7, as well as Aristotle Kallis, Genocide and Fascism. The Eliminationist Drive in Fascist Europe (London, 2009), pp. 26-84. 
finally, unemployed workers seeking a living. From the moment they began to march in the summer of 1941, there were constant incidents involving the civilian population - all of which defy precise quantification - including requisitions, theft, sexual abuse, and some cases of rape.

Spanish soldiers were not habitually involved in the homicide of Russian peasants; in fact, they coexisted reasonably well, given their condition as invading troops in a place such as the Eastern Front. A similar pattern of behaviour towards the civil population has also been signalled for other German divisions of the Army Group North. ${ }^{116}$ A few significant examples have revealed just how non-idyllic these relations were. Many Spanish officers had learned in the colonial wars in Northern Morocco to let their troops find provisions on location, a practice they continued unscrupulously in Russia. ${ }^{117}$ Colonel Díaz de Villages recalled the argument put forward by a Falangist volunteer engaged in a discussion with a German military policeman: 'It would be absurd ... if after seeing so many of ours fall, after suffering such a difficult war, we could not even eat a Russian chicken.'118

The complexity inherent in the presence of an occupying army among civilians led many Spanish soldiers and officers who lodged in the isbas to function as protectors of Russian families, which were mainly composed of young or elderly women, children and old men. The divisionarios would feed and protect them in exchange for services that ranged from lodging and laundry to sexual favours. The low intensity and even absence of biological racism led to a greater degree of familiarity between most Spanish soldiers and Russians civilians. Contrary to Romanian and Hungarian troops in the Army Groups Centre and South, ${ }^{119}$ the Spaniards did not become involved in systematic reprisals or large-scale murders of civilians. They were, nonetheless, responsible for continual theft, requisitioning, and pillaging, along with occasional sexual abuse. This was typical of the experiences of other occupying Axis armies during the Second World War, such as the relatively benign presence of Germans in Norway, Denmark, and the Netherlands. In these countries, the experience of occupation was characterized by a low level of everyday tension, close interactions between occupiers and some segments of the occupied population, and sporadic outbursts of violence, reprisals, and other incidents. ${ }^{120}$ In the

116 As Rutherford (Combat and Genocide, pp. 280-302) suggests for the German 121st and 126th Divisions, while battle conditions fostered greater brutalization among the soldiers of the 123rd Division.

117 See Sebastian Balfour, Deadly Embrace. Morocco and the Road to Spanish Civil War (Oxford, 2002), pp. 215-33, and Gustau Nerín, La guerra que vino de África (Barcelona, 2005), pp. 280-3.

118 Juan Sánchez Carrilero, Crónicas de la División Azul (Albacete, 1992), p. 124.

119 See Anderson, 'A Hungarian Vernichtungskrieg?' as well as Ungváry, 'Das Beispiel der ungarischen Armee.

120 See Robert Bohn (ed.), Die deutsche Herrschaft in den 'germanischen'Ländern, 1940-1945 (Stutgart, 1997); Henning Poulsen, 'Die deutsche Besatzungspolitik in Dänemark', in Robert Bohn et al. (eds), Neutralität und totalitäre Aggression: Nordeuropa und die Großmächte im Zweiten Weltkrieg (Stuttgart, 1991), pp. 369-80, as well as Jennifer L. Foray, 'The "Clean Wehrmacht” in the German-Occupied Netherlands, 1940-1945', Journal of Contemporary History 45.4 (2010), pp. 768-87. 
context of the Eastern Front, this was also characteristic - to some extent - of the occupation policy of the Italian army on the Don Front. ${ }^{121}$ With regards to Spanish troops' behaviour towards Russian civilians in the Volkhov and Leningrad area, what scandalized the Army Group North, influenced by the German military's own stereotypes, was not the lukewarm commitment to the Geneva Convention but the fact that Iberian soldiers were unsystematic in their pillaging. This negatively affected the immediate interests of the Wehrmacht in its attempts to not completely alienate the civilian population.

However, it must not be forgotten that the Blue Division effectively though indirectly aided a strategic action that served the mid-range war of extermination plans behind the invasion of the USSR: the sentencing of three million people to death by starvation. Many Falangist volunteers, officers, and NCOs rejected Russia and the Russians as an Asian people, who they considered to be culturally and spiritually inferior. In addition to blaming Russia and communism for the misery of the peasants, many also accused the submissive and brutish Russians themselves. This view was permeated with commiseration and even empathy, not racial hatred. Spanish soldiers might commit excesses; they felt a certain sense of cultural superiority towards the enemy and civilians, akin to that experienced by North American soldiers facing the Japanese in the Pacific. ${ }^{122}$ But the Blue Division - its commanders, many of its officers, and most of its soldiers - had not envisaged the extermination or subjugation of the Slavic population. Most were convinced that they had come to restore Christian faith and civilization in Russia by eradicating communism. In this they diverged radically from the majority of the soldiers of the Wehrmacht, although not too much from the views held by German Catholic soldiers, or Italian soldiers, on the Eastern Front. ${ }^{123}$

\section{Author Note}

A first version of this article was presented at the research seminar of the Centre for War Studies, University College Dublin, 28 January 2016, and the Sheffield Modern International History Group,

121 See Thomas Schlemmer, Die Italiener an der Ostfront 1942/1943. Dokumente zu Mussolinis Krieg gegen die Sowjetunion (Munich, 2005), pp. 368-97; a more nuanced perspective on the Italian treatment of civilians, based on post-war Soviet documents, is offered by Giorgio Scotoni, Il nemico fidato. La guerra di sterminio in URSS e l'occupazione alpina sull'Alto Don (Trento, 2013), pp. 218-23, 286-300, who underlines the benign character of Italian occupation in comparison with German behaviour towards civilians and prisoners of war.

122 See Peter Schrijvers, The GI War against Japan: American Soldiers in Asia and the Pacific during World War II (Basingstoke, 2002).

123 See Nicholas Stargardt, Der deutsche Krieg 1939-1945 (Frankfurt a.M., 2015), pp. 207-8, as well as Thomas Schlemmer, 'Gefühlsmassige Verwandtschaft? Zivilisten, Kriegsgefangene und das königlich-italienische Heer im Krieg gegen die Sowjetunion 1931 bis 1943', in Lutz Klinkhammer, Amedeo Osti-Guerrazzi, and Thomas Schlemmer (eds), Die 'Achse'im Krieg. Politik, Ideologie und Kriegführung 1939-1945 (Paderborn, 2010), pp. 368-97. 
University of Sheffield, 6 May 2016. I would like to thank all participants, as well as the anonymous reviewers of War in History, for their insightful comments, which have enriched the text.

\section{Funding}

This research received no specific grant from any funding agency in the public, commercial, or not-for-profit sectors. 